\title{
The Challenges of Accounting Education: The Nigerian Experience
}

\author{
Okolie Onyeisi Romanus ${ }^{1}$ M. Sc, ACA \& Amos Arowoshegbe ${ }^{1} \mathrm{PhD}$, ACA \\ ${ }^{1}$ Department of Accounting, Ambrose Alli University, Ekpoma, Edo State, Nigeria \\ Correspondence: Amos AROWOSHEGBE, PhD, ACA, Department of Accounting, Ambrose Alli University, \\ Ekpoma, Edo State, Nigeria. Tel: 234-80-5881-5935, 234-80-3742-2421 E-mail: Futona4christ2@gmail.com
}

Received: March 1, 2014

Accepted: April 5, 2014

Online Published: April 21, 2014

doi:10.5430/afr.v3n2p129

URL: http://dx.doi.org/10.5430/afr.v3n2p129

\begin{abstract}
The paper reviewed the development of accounting education in Nigeria and the challenges confronting it. It critically examined the state of the profession and the dynamics that will help to build implicit confidence in the Accountant, mould his character and develop analytical mindset which will assist him to provide high standard of professional services. The objective of the paper is to identify the factors that have hindered the adequate and rapid development of accounting profession in Nigeria. These factors were highlighted under the section of challenges facing accounting education in Nigeria. Also the need for accounting education was examined and recommendations were made. It concluded that there is urgent need for effective training and retraining of practicing Accountants, for adequate provision of funds for the education sector and regular review of accounting curriculum to capture modern trends in Accountancy.
\end{abstract}

Keywords: Accounting Research, Challenges, Curriculum, Accounting Education, Accountant

\section{Introduction}

Accounting as a profession has a very important role to play in the economic development of any nation. As a measurement and reporting information system, the profession can cover both micro and macro economic activities. It consists of various subsystems with related economic events and decisions (Ajayi, 1997). These subsystems which can be identified as the major accounting fields include; business accounting, government accounting, social accounting, auditing and taxation, all of which aid in economic planning, project appraisal, capital formation and so on (Badejo 1997).

The American Accounting Association (AAA 1986) states that the function of accounting is to provide qualitative information, primarily financial in nature, about economic entities that is intended to be useful in economic decisions. This information allows users to make reasoned choices among alternative uses of scarce resources in the conduct of business and economic activities. The need for accounting therefore arose in response to the desire to make judicious use of scarce resources, accumulate wealth and produce high quality of goods and services in a competitive economy. To perform these roles, accountants are needed both in number and in quality and this is a function of the level of accounting education available (Armstrong, 2010).

An appropriate level of accounting education must embrace the development of the character of the aspiring accountant in such a manner as to engender in him or her a strong moral code; a sense of discretion; an almost total commitment to the confidentiality of information or data established as a result of work carried out; an enquiry and analytical mind consistent with providing clients with high standards of professional services; an ability to assess data and situations and to prepare reports in such a way as to impress upon users of accounting services that their problems have been addressed in ways consistent with the highest ideals of a true professional, a sense of dress and carriage designed to develop a confidence in the competence and probity of the practitioners within the profession (Kimmel, 1995; Maher,2000;Ravenscroft \& Williams, 2003). The objective of this paper is to examine the challenges confronting accounting education in Nigeria.

\section{Literature Review}

The study of accounting must not only be in form of practical education, but must be a combination of both sound practical education and theoretical knowledge. This will enable the accountant to utilize modern accountancy techniques in finding solutions to complex business problems. The need for accounting arose as a result of the expansion and complexity of business enterprises. And also the desire for stewardship reporting, accountability and 
reliable accounting information (Ogundele, 1991 and Chua, 1990). Accounting education can be looked at from two perspectives, it can be used to describe education for accountants, in other words, those instructions designed to be necessary for potential accountants to acquire in order to gain their professional qualifications. It can also be used to describe the expansion and extension of knowledge and the development of judgement of those who have already become accountant (Albrecht and Sack 2000 and Brewer, 2000). Thus, to maintain professionalism, accountants must be abreast with the release of both local and international standards and emerging theoretical postulations. With the continuous development of standards, new accounting procedures, and changes in the business and economic spheres coupled with the risk of being found negligent and therefore incompetent in the discharge of his duties, a professional accountant who neglects the need for accounting education does so at the risk of his professional life, (Reiter \& Williams 2002; Ravenscroft \& Williams 2003). This paper is motivated by our belief that accounting education today is plagued with many serious problems and our concern that if those problems are not seriously addressed and overcome, they will lead to the demise of accounting education.

\subsection{Accounting Profession in Nigeria}

According to Wintoki (1997) and Coker (1990) the development of accounting in Nigeria can be traced to the time when the Companies Ordinance of 1922 was enacted. The second major development of accounting education and training in Nigeria took place in the early 1960s, when the Colleges of Arts, Science and Technology were established in Ibadan, Enugu and Zaria in 1963, (Uche 2003). The development of the accounting profession in the country has been assisted by the establishment of the department of accounting in the Nigerian universities, polytechnics and colleges of technology (Badejo, 1997; Ajayi, 1996).

It is quite natural to expect the profession in Nigeria to inherit the accounting system of its colonial master-Great Britain. In this regards, the local accountants were trained on their job. However, some of them left the country to study accounting and accounting related courses, while those who did not travel abroad took the external examination of the Institute of Chartered Accountants of England and Wales. Just after the country's independence the idea of establishing a professional body of accountants in the country became a burning issue in the minds of a few accountants. This led to the establishment of "The Association of Accountant of Nigeria", which was incorporated under the Companies Act of 1958. The main objectives of the Association were to provide a central organization for accountants in the country, to maintain a strict standard of professional ethics, and to provide for the training, examination and local qualification of students in accounting (Ofoibike, 1992; Maduka \& Adebowale, 2009). It was not until 1965 that an Act of Parliament was passed establishing the Institute of Chartered Accountants of Nigeria (ICAN). In 1993, another accounting body known as Association of National Accountants of Nigeria (ANAN) was established. Based on the foregoing, it is not surprising that it was the Nigerian members of the Association of Chartered Certified Accountants (ACCA) that first moved to set up a professional accountancy body in Nigeria in 1957. In that same year, they applied to form a local branch of the ACCA. This plan was endorsed by the ACCA in London in 1960. Nigerian members of ACCA saw clear advantages in the newer idea of forming a local accountancy body that would bring all Nigerians with overseas accountancy qualifications of equivalent standards together (Uche, 2003; Ogbomo, 1997).

\subsection{Need for Accounting Education}

There is no business undertaking where the use of money is not important. The financial resources of any business entity backed by a sound management determines the success or misfortune of such an undertaken, therefore, there is no business entity where accountants will not be required. Accounting recognizes that people live in a world of scare resources. Because resources exist in limited supply, people try to conserve them, to use them efficiently and also to identify and encourage those who make efficient use of them. Through an efficient use of resources, the standard of living increases. Accounting plays an important role in obtaining a higher standard of living because it helps to identify efficient and inefficient users of resources (Anibaba, 1990; Dyer, 1999).Also identifying the need for accounting education, Wolcott (2010) noted that "There is little doubt that the current content of professional accounting education, which has remained substantially the same over the past 50 years, is generally inadequate for the future accounting professional. A growing gap exists between what accountants do and what accounting educators teach....Accountants who remain narrowly educated will find it more difficult to compete in an expanding profession"

The training and education of an accountant take such a form that would mould him in such a way as to make him display such rare attributes as the maintenance of a strict standard of professional skill, expertise and ethics, as not to want to be associated with failure, fraud or embezzlement or unnecessarily wanting to rock the boat, (Inanga 2000; Sterling 2003). Globally, accounting education involves the impartation of knowledge in accounting principles and standards to individuals. It could also take the form of contributing to a body of an established knowledge or procedure. 
It is thus out to inform, review a set of process and inculcate in the trainee, a high standard of professional education as demanded by his calling (Ibironke, 2003). In the emerging order, education has become the single most important factor that determines living standards. New growth processes are increasing the demand for skill labour far more rapidly than for unskilled labour and the distribution of opportunities for education is becoming the prime determinant of income distribution (Durukwuaku, 1997; Ogbomo, 1997)

The need of the Nigerian economy for the education and training of accounting manpower was summarised by Inanga, (2000); Wintoki, (1997); Ogbomo, (1997) as follows; to ensure that Nigerian accountants are of comparable standard with their counterparts across the world; to guarantee that each qualified accountant is well trained, acquires sufficient skills required of a professional accountant and that the skills are demonstrated in his operations; to maintain and sustain the dignity and respect of the Nigerian accountancy profession; to ensure that each accountant can justify the standard of the certificate awarded; to produce enough manpower to man accounting jobs; to produce professionals with sound training to meet the shortage in the country of competent accountants; to establish and enhance the profession as it relates to the application and developments of accounting disciplines, to develop and upgrade the professional skills, and competence of members; to enable them participate actively in an environment that is business oriented and complex and to catch up with technological advancement in the areas of accounting and financial management, possibly through financial display of statistical information that has relevance to the society.

\section{Challenges facing Accounting Education in Nigeria}

The challenges confronting the accountant in his role to the society at large in a dynamic and complex environment have been a great concern to the accounting profession. This great challenge borders on how the profession, using the education of the members and would be members can adapt its focus in such a way that clients will appreciate the service rendered, (Reiter \& Williams, 2002; Kimmel, 1995; Boer, 2000). The following among others, are the challenges facing accounting education in Nigeria:

\subsection{Institutions}

Sir Eric Ashyby headed the commission on post secondary and Higher Education in Nigeria in 1960. It was the commission that recommended that commercial programmes should be offered by higher schools and universities, (Ajayi, 1997). The development of the accounting profession in the country has been assisted by the establishment of universities, polytechnics and colleges of technology. The system of accrediting accounting departments by National Universities Commission (NUC), National Board for Technical Education (NBTE) and ICAN have helped to improve the standard and quality of programmes in the institutions in providing accounting education for the manpower requirements for the governments and parastatals, industry and commerce and for the accounting professional offices, (Ogundele 2010; Adegbiyi 1997). Also the establishment of Nigerian Accounting Standard Board in 1982, which has now metamorphosed to Financial Reporting Council of Nigeria (FRCN), is saddled with the responsibility of setting local accounting standards in conformity with international standards. This is to ensure uniformity and improved standard in the financial reporting process in Nigeria. Although there has been steady growth in the number of institutions offering accounting over the years, but these institutions have not been able to admit the large number of candidates applying to them to study accountancy (see table 1 below).

Table 1. Number of Tertiary Institutions Offering Accounting Courses in Nigeria

\begin{tabular}{llll}
\hline Programmes & College & Polytechnic & University \\
\hline Federal & 19 & 18 & 54 \\
State & 39 & 30 & 25 \\
Private & - & 10 & 22 \\
Total & $\mathbf{5 8}$ & $\mathbf{5 8}$ & $\mathbf{6 8}$ \\
\hline
\end{tabular}

Source: JAMB Brochure (2011)

This has therefore greatly affected the training of accountants for both the private and public sectors of the economy and also those in practice as the economy is expanding daily. The improvement in the number of well-equipped institutions offering accountancy will no doubt, improve the number and quality of accountancy graduates.

\subsection{Role of Accounting Research}

Some of the factors inhibiting the progress of accounting education in Nigeria are inadequate research facilities and non-availability of up-to-date books, as well as professional and academic journals on accounting (Enthoven 2002; Adewumi, 1999). Research has been defined as a studious inquiry or examination especially critical and exhaustive 
having for its aim the discovery of new facts and their correct interpretation, the revision of laws in the light of newly discovered facts or the practical application of such new or revised conclusions, theories or laws, (Boer, 2000; Sterling, 2003). Research in accounting education therefore is a continuous process, as in other professions and disciplines, which has kept the practitioners on in adapting to the vagaries and changes in the environment in which they practice and which are brought to bear on their existing knowledge, (Ravenscroft \& Williams, 2003; Reiter \& Williams 2002;Birnberg, 2000).

Research generates knowledge, and teaching helps people to acquire and use it. It is universally accepted that part of the obligations of the academics is to conduct research. It is equally obligatory for members of the profession to provide sound education to its members both before and after qualification, (Birnberg, 2000; Rebele, Stout \& Hassell, 1991). According to Olagunju (2011); Anao (1995) at the present level of the country's development, research can play key roles in further development of accounting education such as curriculum development in the tertiary institutions and for the profession. However in Nigeria, there has not been in-depth research into accounting principles and practices in the face of global challenges. The results of such research are expected to provide latest accounting techniques, new theoretical knowledge and the discovery of new accounting packages that will meet both local and international standard. It is hoped that if adequate fund is provided, academics and practitioners will be encouraged to research into different aspects of accounting (Odiaka \& Nwachukwu, 2008).

\subsection{The Teacher}

According to Adegbiyi (1997); Adewumi (1999) the dearth of accounting teachers in tertiary institutions is profound and very alarming. This is due to the poor remuneration of accounting lecturers when compared with what their counter parts in the private sector earn. These institutions lack the capability to attract accounting lecturers to the various accounting departments this is perhaps due to the low motivation and low pay when compared with what their counter-parts working in business firms earn (see table 2 below).

Table 2. Staff List of some Universities in Nigeria

\begin{tabular}{llllllll}
\hline University & Professor & $\begin{array}{l}\text { Associate } \\
\text { Professor }\end{array}$ & $\begin{array}{l}\text { Senior } \\
\text { Lecturer }\end{array}$ & $\begin{array}{l}\text { Lecturer } \\
\text { I }\end{array}$ & $\begin{array}{l}\text { Lecturer } \\
\text { II }\end{array}$ & $\begin{array}{l}\text { Assistant } \\
\text { Lecturer }\end{array}$ & $\begin{array}{l}\text { Graduate } \\
\text { Assistant }\end{array}$ \\
\hline ABU & 1 & & 6 & 9 & 6 & 2 & 7 \\
Babcock & 2 & 1 & 6 & 2 & 2 & & 2 \\
Ilorin & & 3 & 5 & 7 & 5 & 4 & \\
Osun State & 6 & 2 & 6 & & 4 & 2 & \\
AAU, Ekpoma & 1 & 1 & 3 & 1 & 3 & & \\
Unilag & 2 & 2 & 4 & 2 & 4 & & \\
Convenant & & & 2 & 4 & 4 & 5 & \\
UNN & 1 & & 4 & 7 & 1 & & \\
Unizik & 2 & 3 & 5 & 6 & 3 & 1 & \\
AjayiCrowther & & & 1 & 3 & 1 & 1 & \\
Unical & 2 & 2 & 4 & 3 & 4 & 2 & \\
Uniport & 1 & & 3 & 2 & 5 & 3 & \\
Uniben & 2 & 2 & 5 & 8 & 6 & 7 & \\
Caleb & 1 & 1 & & 1 & 2 & & \\
Delsu & & 2 & 1 & 7 & 5 & 1 & \\
Salem & & 2 & 2 & 1 & 2 & 1 & \\
Bowen & 1 & & 4 & 2 & 1 & & \\
Lead City & 1 & 1 & 5 & 2 & 2 & 3 & \\
Nasarawa & 2 & 1 & 3 & 3 & 2 & 1 & \\
State & & & & & & & \\
Adamawa & & 1 & 4 & 3 & 2 & 3 & \\
State & & & $\mathbf{2 4}$ & $\mathbf{7 3}$ & $\mathbf{7 3}$ & $\mathbf{6 4}$ & $\mathbf{3 6}$ \\
Total & $\mathbf{2 5}$ & $\mathbf{2 4}$ & & & & & \\
\hline
\end{tabular}

Source: Website of the Universities (2012) 
In addition, lack of adequate facilities and materials has totally rendered the teachers helpless in their bid to impart knowledge on their students. The teacher needs an enabling environment to maintain effectiveness in their teaching process. This will also enable him to select learning experiences, diagnose learning difficulties and guide learning in order to improve the instruction process. It has been observed that the shortage of teachers in these institutions has affected the number of students that can be admitted in these institutions (Ogbomo, 1997; Adewumi, 1999). The following are also the major deficiencies that have been identified as inhibiting the growth of accounting profession in the Third World; a dearth of qualified and dedicated accounting and managerial personnel; inadequate, unreliable and untimely databases, ineffective systems of internal control, inadequate technology and data processing systems, poor and inefficient management process (Gharetey, 1990). There are no chairs in most of the Department of Accounting in the universities and polytechnics. Besides, it is not also enough to have these chairs in accounting, it is equally important to encourage persons with appropriate qualifications to take leave of absence to occupy these chairs (Ogbomo, 1997; Thorne, 2010).

\subsection{Funding}

Available statistics on primary, secondary and tertiary institutions enrolment over the yeas show a geometric increase while the government recurrent and capital allocations for education has been on a steady decline in real terms (Anibaba, 1990;Imudia\&Ojekhere, 2012). The effect of under-funding of the educational system is what is found in the various educational institutions today. These include the dilapidated physical facilities at all levels. Irregular and at times non-payment of teachers' salaries, abandonment of capital projects and lack of physical developments in these institutions have resulted in frequent strike by school teachers, lecturers and workers at all levels of education, thereby causing disruption of academic activities (Ogbomo, 1997; Otunsanya, 2003). Accounting as one of the various disciplines in these institutions has suffered the same faith from the poor funding. It is evident that the percentage allocated to education is far less than the $26 \%$ recommended by United Nations Educational, Scientific and Cultural Organisation (UNESCO) that nations should allocate to education from their national budget. This has no doubt affected the development of education in Nigeria, and by implication, accounting education (see table 3 below).

Table 3. Nigerian Budget for Education

\begin{tabular}{llll}
\hline Year & Total Budget & $\begin{array}{l}\text { Amount allocated } \\
\text { to Education }\end{array}$ & $\begin{array}{l}\text { Percentage of Amount } \\
\text { allocated to Education }\end{array}$ \\
\hline & N trillion & N trillion & $\%$ \\
2001 & 0.894 & 0.063 & 7.2 \\
2002 & 0.840 & 0.068 & 8.1 \\
2003 & 1.446 & 0.110 & 7.6 \\
2004 & 1.189 & 0.100 & 8.4 \\
2005 & 1.618 & 0.150 & 9.3 \\
2006 & 1.880 & 0.167 & 8.8 \\
2007 & 2.301 & 0.189 & 8.2 \\
2008 & 2.450 & 0.220 & 8.9 \\
2009 & 2.870 & 0.184 & 6.4 \\
2010 & 4.600 & 0.295 & 6.4 \\
2011 & 4.840 & 0.306 & 6.3 \\
2012 & 4.749 & 0.400 & 8.4 \\
2013 & 4.920 & 0.426 & 8.6 \\
\hline
\end{tabular}

Source: www.fmf.gov.ng and www.budgetoffice.gov.ng (2013)

\subsection{Curriculum}

Brewer (2000); Kimmel (1995);Deakin \& Summers (1975) noted that the focus of a programme should extend beyond technical skills and emphasize the personal capacities of students to interact well with one another, assume responsibilities, reason logically, think creatively, embrace ethical standards and conduct and communicate effectively. Hence accounting curriculum must be structured to achieve this objective. In fact, it is being suggested that at least 150 hours of college study are needed at the minimum to mould a student into being an accountant (Olagunju, 2011)

The curriculum for the accounting profession must produce products who have acquired broad array of skills which include: interpersonal, communication, intellectual and other skills for public accounting. Future accountants must also possess knowledge in organizational administration, business, accounting, audit apart from general knowledge and 
knowledge in for public accounting. These attributes are essential to ensure that the accountants are able to use data, exercise judgements, evaluate risks and identify and solve real world problems (Albrecht and Sack 2000; Anibaba 1990 and Enthoven 2002). The world is really a global village, with a lot of development in the area of technology, with so many accounting packages and products. French and Coppage, (2000) and Albrecht and Robert (2000) had predicted that the work and training of accountants will change radically due to developments in theories and information technology. However the current curriculum is not flexible enough to incorporate these new developments in accounting standards, guidelines, theories and information technology and this has affected the quality of graduates from the various higher institutions of learning.

\section{Recommendation}

If accountants are to adapt to the pressures of change and contribute maximally to organizational and societal progress, they must, in addition to their specialized skills, also have a foundation of a broad-based education. This will enable them to develop a balanced outlook on issues of wider ramifications beyond their accounting specialty. They will then appreciate fully how their decisions and actions within their own specialty interface with those of other specialties, and the eventual implications for the entire organizational or societal fortunes. First, it must ensure that its members are professionally competent to meet the needs of the members of the public, and not only their clients who rely on their services. Second, it should ensure that, its members maintain, throughout their professional life, the quality of the services and expertise that society expects from them. In a nutshell, the profession must concern itself not only with the pre-qualification education of its members, but also with their continuing education if it is to sustain its relevance in the present day business environment (Agbebiyi, 1997 and Maher, 2000).

The need for specialization within the profession should be addressed and the syllabus appropriately amended so that students should only take subjects relevant to their chosen area of specialization. One can have B.Sc. Accounting in (Taxation, Auditing, Financial Management and so on.), (Arnold, 2000; Adhikari, 2011).

The prevailing situation definitely suggests that Nigeria is one of the countries which have not fared appreciably in adapting the accounting discipline to its economic development. Another aspect of the problem of inculcating relevant knowledge is the need to re-organise, redesign and restructure the curriculum for the training of accountants so as to remove the prevailing structures of narrowness and stereotype (Agbebiyi,1997;Ogbomo 1997). Consequently the direction of growth of the profession must be in terms of becoming more expert in solving societal problems and in seeking new ways to contribute to societal satisfaction or well-being and thus ensuring for itself continuing relevance (Ibironke, 2003; Gaine \& Locatelli, 2011;Anao, 1991).

Education is a continuing need in society. Accounting education therefore should evolve from a continuing relationship and dialogue between academia on one hand and the accounting professionals on the other. It should not be seen as an end in itself (especially in the "production" of competent accountants and accounting technicians) but as a means to an end - which is to facilitate accountability in both public and private sectors of the economy. The current state of the accounting education is inadequate. It must be raised and redirected to meet the needs of the growing profession and of future accounting professionals. The focus of the profession will extend beyond technical skills and will emphasize on the personal capacities of students to interact well with others, assume responsibilities, reason logically, think creatively, embrace ethical standard and conduct, and communicate effectively (Uche,1997; Inanga, 2010;Badejo, 1997).

It is also important to note that the accounting profession must distinguish between professional and academic qualifications. There is the very need to separate academics and professionalism. Theories and conceptual framework of disciplines cannot be treated in total isolation from practice. It is imperative to note that the professional qualification is the concluding process of the journey studied by obtaining academic qualification and professional clearance through requisite training and successful completion of the professional examinations, (French and Coppage, 2000; Chua, 1990). There is need to step up the production of qualified accountants so as to bring the country's present ratio of only 1 accountant to every 10,000 Nigerians to somewhere nearer the United Kingdom (UK) ratio of 1:500 or United States of America (USA) ratio of 1 to approximation 700. The wide divergence between the Nigerian ratio and those of the UK and USA referred to may indeed serve to explain the wide disparity in the respective levels of economic development, (Anao, 1995).For optimum result to be achieved there should be mutual agreement and coherence between accountants in academia and those in active practice in policy regarding goals, training process and strategies and in curriculum content, (Arnold, 2000; Annisette,2012). In the classroom we need to provide more opportunities for students to think seriously about the legitimate reciprocities that exist between business entities and the various constituents that are affected by them. It is important to impose rules on students assignment deadlines, this is important and must be respected. Students should be encouraged to ask questions and be clearified in 
complicated areas. Lecturers should be interested in students' feedback information so as to improve on their lecture delivery process. Attentions should also be paid to those students that show low interest in lectures and the reason for such poor attitude should be investigated. Lecturers have to ensure maximum attendance of students in class (Adebanjo \& Olajide, 2009).

Private individuals and corporate bodies consume education by way of making substantial use of the end products of education without making substantial financial contribution except little sponsorship by way of scholarships which is just a drop in the ocean. It has been identified that one of the reasons for fewer professional accountants in Nigeria relative to other professionals, is that the other professional bodies, such as law, medicine, engineering and so on had established programmes in tertiary institutions. Part of the strategy for addressing this problem is the sponsorship of research projects of doctorial and masters degree students in accounting and related fields in tertiary institutions. The dearth of accountants thus identified called for accelerating the training of more accountants (Ogundele, 1991; Badejo, 1997; Adewumi, 1999).

A deliberate policy of encouraging interchange of personnel between theory and practice will, at one end, help the teacher to concretise and distil his theoretical knowledge making him better able to prepare the would be accountant for an after school career and at the other end, provide opportunities for the practitioner to acquaint and update himself constantly with the newer concepts and techniques emerging in the profession, (Boer, 2000; Sterling, 2003). The improvement of accounting education in Nigeria should be pursued not only with the envisaged deepening and broadening of the knowledge base, but also through the strict enforcement of professional ethics. More attention should also be given to the publicity and propagation of the accounting policies and programmes as well as to cases of discipline of erring members (Ofobike, 1992; Uche, 2003). The education of accountants must lay emphasis on expertise including specialized body of knowledge, skill and competence over which it claims exclusive jurisdiction and authority (French \& Coppage, 2000;Anao, 1995)

\section{Conclusion}

This paper has examined the challenges of accounting education in Nigeria and made some recommendations. We posit that there is the need to encourage and foster the adoption of potent modern accounting and financial management techniques in Nigeria. The changing socio-economic environment of accounting exerts continuing pressures on accounting to constantly review its goals, concepts and methodologies. Accounting as a discipline must continue to examine issue which may be continuously explored for possible refinement, adaptation or modification.

Professional accountancy service has not been secured adequately for economic developmental needs of the country, while the professional training programmes and research are neither linked effectively to these needs nor do they portray future requirements of accounting.

The responsibilities of the accountancy profession include ensuring that members are professionally competent to meet the needs of the members of the public, and not only their clients who rely on their services. Secondly, it should ensure that, its members maintain, throughout their professional life, the quality of the services and expertise that society expects from them. In a nutshell, the profession must concern itself not only with the prequalification education of its members, but also with their continuing education if it is to sustain its relevance in the present day business environment. There is the need to look into the future and ensure that the right steps are taken to guarantee the right place for the profession in future, bearing in mind that accounting is an international profession, the practice of which is affected by technological developments in any part of the world. With the right direction and work, accounting education has a bright future. That future depends upon the actions we take today.

\section{References}

American Accounting Association (AAA). (1986). Committee on the Future Structure, Content, and Scope of Accounting Education, (the Bedford Report), "Future Accounting Education: Preparing for the Expanding Profession", Issues in Accounting Education, Spring, pp. 168-195.

Adebanjo, K. L. \& Olajide, U. E. (2009). The Use of Technology in the Delivery of Instruction: Implications for Accounting Educators and Education Researchers. Issues in Accounting Education 15(1): 129-162.

Adewumi, O. (1999). "Strategic Framework for Enhanced Continuing Professional Education in Accounting", $29^{\text {th }}$ Annual Accountants ICAN Conference Proceeding, Abuja.

Adhikari, P. (2011). Credibility Question in Accounting Profession, New Business Age. Retrieved $5^{\text {th }}$ May, 2012 from htt://.New business age.Com/sectoral/452.

Agbebiyi, H. A. (1997). "Testing, Grading and Evaluation of Students Performance: Challenges and Prospects. (Ed, E. O. Adegite) Lagos, University of Lagos Press pp 65-77. 
Ajayi, C. A. (1997). "The Development of Accounting Profession in Nigeria". Accounting Education in Nigeria: Challenges and Prospects. (Ed, E. O. Adegite) Lagos, University of Lagos Press pp 3-11.

Ajayi, C. A. (1996). "The Role of University in the Training and Education of Accountants in Nigeria: Past, Present and Future" (Ed. E. O. Ogunjimi and S. O. Aderemi) pp 88-97.

Albrecht, W. S. \& Robert, J. E. (2000). A Review of Empirical Research in Accounting Education: 1985-91. Journal of Accounting Education 9, 167-231.

Albrecht, W.S. \& Sack, R.J. (2000). Accounting Education: Charting the Course through a Perilous Future. American Accounting Association. Accounting Education Series, vol. 16.

Albrecht, W.S. \& Sack, R.J. (2001). The Perilous Future of Accounting Education. The CPA Journal 71, (3), 16-23.

Anao, A. R. (1995) The Accountancy Profession and Nigerian Economic Development. Nigerian Accountant (Vol. 28 No. 2 July/ September) pp 21-32.

Anao, A R. (1991). "Enhancing Transparency and Accountability in the Public Sector" A Paper Presented at the Forum of Accountants General and Auditors General of West Africa in Abuja. January 25-26.

Anibaba, M. O. (1990). "A Short History of Accounting Profession in Nigeria”. West African Book Publishers Limited, Lagos.

Annisette, M. (2012). Imperialism and the professions: the education and certification of accountants in Trinidad and Tobago, Accounting, Organizations And Society, Vol. 25, No. 7, pp. 631-659. http://dx.doi.org/10.1016/S0361-3682(99)00061-6

Armstrong, M. B. (2010). 'Ethics and Professionalism in Accounting Education: a Sample Course', Journal of Accounting Education, vol. 11, no. 1, pp. 77-92. http://dx.doi.org/10.1016/0748-5751(93)90019-F

Arnold, J. (2000). "Research in Accounting and Finance: Methods and Prospect". The Nigerian Accountant (Vol. 33 No2, April/June) pp 6-14.

Badejo, A. O. (1997) "Objectives and Features of Professional Education and Training": Accounting Education in Nigeria: Challenges and Prospects (Ed, E. O. Adegite) Lagos, University of Lagos Press pp 13-20.

Birnberg, J.G. (2000). The Role of Behavioural Research in Management Accounting in the 21 Century. Issues in Accounting Education, 15, (4), 713-728. http://dx.doi.org/10.2308/iace.2000.15.4.713

Boer, G.B. (2000). Management accounting education: Yesterday, today, and tomorrow. Issues in Accounting Education, 15, (2), 313-333. http://dx.doi.org/10.2308/iace.2000.15.2.313

Brewer, P.C. (2000). An Approach to Organising a Management Accounting Curriculum. Issues in Accounting Education. Issues in Accounting Education, 15, (2), 211-235. http://dx.doi.org/10.2308/iace.2000.15.2.211

Chua, W.F. (1990). "Radical Developments in Accounting Thought", The Accounting Review, Vol.LXI, No. 4, October, 1986, pp. 601-632.

Coker, F. C. O. (1990). "How it All Started". The Nigerian Accountant (Vol.23 No. 3 August/September )pp 23-24.

Deakin, E.B., \& Summers, L.S. (1975). A Survey of Curriculum Topics Relevant to the Practice of Management Accounting. The Accounting Review, April, 380-383.

Durukwuaku, S. C. (1997). "Instruments for Measuring Teaching Effectiveness of Accounting Education" Accounting Education in Nigeria: Challenges and Prospects (Ed, E. O. Adegite) Lagos, University of Lagos Press pp 105-118.

Dyer, J.L. (1999). Accounting Education on the Threshold of a new Century. The Government Accountants Journal 48, (4), 40-47.

Enthoven, A. J. H. (2002). Accounting Education: Its Importance and Requirement. $5^{\text {th }}$ International Conference on Accounting Education, Canada. pp 10-13.

French, G.R. \& Coppage, R.E. (2000). Educational issues challenging the future of the accounting profession. Ohio CPA Journal 59, (3), 69-73.

Gainen, J. \& P. Locatelli. (2011). Assessment for the New Curriculum: A Guide for Professional Accounting Programs. Accounting Education Series, Vol. 11.

Sarasota, FL: Accounting Education Change Commission and American Accounting Association.

Ghartey, J. B. (1990). Political Accountability and Development in the Third World. International Journal of Public Sector Management pp 39-59 1990. http://dx.doi.org/10.1108/09513559010138497

Helmkamp, J. G; Imdieke, L. F. \& Smith, R. E. (1983). Principles of Accounting. New York, John Wiley and Sons U. S. A. 1983. 
Ibironke, A. (2003). The Collapse of Eron Corporation: Challenges to the Accounting Profession A Paper Presented at the ICAN Mandatory Continuing Professional Education Lagos.

Imudia, F. G. \& Ojekhere, K. C. (2012). Corporate Collapse: Accounting, Regulatory and Ethical Failure, The Nigerian Accountant June/August Vol 36 No 3.

Inanga, E.J. (2010). Teaching Financial Statement Analysis: A Cooperative Learning Approach, Journal of Accounting Education, Vol. 14, No. 1, pp.107-111.

Inanga, E. J. (2000). A Review of Empirical Research in Accounting Education: 1990-1998. Journal of Accounting Education 9, 167-231.

Joint Admission and Matriculation Board (JAMB). (2010). University Tertiary Matriculation Brochure, Lagos Government Press, Lagos.

Kimmel, P. (1995). A Framework for Incorporating Critical Thinking into Accounting Education. Journal of Accounting Education 12(3), pp. 299-318. http://dx.doi.org/10.1016/0748-5751(95)00012-B

Maduka, O. A. \& Adebowale, H. M. (2009). Communication Skills in Accounting Education: Perceptions of Academics, Employers and Graduate Accountants. Accounting Education Journal Vol. 3 p 205.

Maher, M.W. (2000). Management Accounting Education at the Millennium. Issues in Accounting Education, 15, (20), 335-346. http://dx.doi.org/10.2308/iace.2000.15.2.335

National Bureau of Statistics. (2010). Government Printing Press, Lagos.

Odiaka, L. D. \& Nwachukwu, A. J. (2008) Institutional Pressures on University Accounting Education, Contemporary Accounting Research, p 141.

Ofobike, E (1992). Capital Resource Allocation in the Emergent Nigerian Economy The Nigerian Accountant Vol. XXV No 1 Jan/March.

Ogbomo, O. O. (1997). Research into Accounting Education in Nigeria: Challenges and Prospects (Ed, E. O. Adegite) Lagos, University of Lagos Press pp 35-43.

Ogundele, B. (1991). In Our Opinion- Accounting and the Society. $41^{\text {st }}$ Inaugural Lecture, University of Ilorin, Ilorin, 1991 pp 3-8.

Ogundele, B. (2010). "The Accounting Profession in Nigeria: An International Perspective". The International Journal of Accounting Education and Research Vol. 3 No 1 pp 101-106.

Olagunju, A. (2011). An Empirical Analysis of the Impact of Auditors Independence on the Credibility of Financial Statement in Nigeria. Research Journal Financial and Accounting Vol 2.No.3 Retrieved on $25^{\text {th }}$ August, 2012 from http. //www,//ste.Org/journals/index. PHP /RJFA/article/download/329/218

Otunsanya, S. N. (2003). The Quality of Learning in Accounting Education: the Impact of Approaches to Learning on Academic Performance', Accounting Education, vol. 8, no. 4, pp. 277-300.

Sterling, R. R. (2003) Research Methodology in Accounting, Houston, Scholar Books Company.

Ravenscroft, S. \& P.F. Williams. (2003). Considering accounting education post Enron. Working paper, Iowa State University.

Rebele, J. E., D. E. Stout, \& J. M. Hassell. (1991). A Review of Empirical Research in Accounting Education: 1985-91. Journal of Accounting Education 9, 167-231. http://dx.doi.org/10.1016/0748-5751(91)90003-A

Reiter, S.A. \& P.F. Williams. (2002). The Structure and Progressivity of Accounting Research: The Crisis in the Academy Revisited. Journal of Accountancy. 27 (6), 575-607.

Thorne, L. (2010). 'Refocusing Ethics Education in Accounting: An Examination of Accounting Students' Tendency to use their Cognitive Moral Capacity', Journal of Accounting Education, vol. 19, no. 2, pp. $103-17$. http://dx.doi.org/10.1016/S0748-5751(01)00014-8

Uche, C. U. (2003). "Professional Accounting Development in Nigeria: Threats from the Inside and Outside" Accounting, Organisation and Society. Vol.27 pp 471-496. http://dx.doi.org/10.1016/S0361-3682(01)00007-1

Uche, C. U. (1997). How to Restructure an Accounting Course to Enhance Creative and Critical Thinking. Accounting Education: A Journal of Theory, Practice and Research 1(1), pp. 49-66.

Wintoki, M. B. (1997). Research into Accounting Education in Nigeria: Challenges and Prospects. (Ed, E. O. Adegite) Lagos, University of Lagos Press pp 45-57.

Wolcott, S. K. (2010). Critical Thinking Development in the Accounting Curriculum: Focusing on Ambiguity in Introductory Accounting Courses. In D. F. Fetyko (Ed.) Changes in Accounting Education: Implementation in Specific Accounting Courses and Subject Areas (pp. 12-15). St. Louis: Federation of Schools of Accountancy. 